\title{
Peningkatan Kesadaran Hukum Mahasiswa terhadap Kejahatan Body Shaming dan Cyber Bullying di Universitas Muhammadiyah Metro
}

\author{
Deni Achmad ${ }^{1 \star}$, Meizano Ardhi Muhammad², Depri Liber Sonata ${ }^{3}$, Heni \\ Siswanto ${ }^{1}$, Haykal Ahmadi Kautsar ${ }^{4}$, Muhammad Giatama Sarpta ${ }^{4}$

\footnotetext{
${ }^{1}$ Hukum Pidana, Universitas Lampung, Bandar Lampung, 35145, Lampung, Indonesia

3 Hukum Perdata, Universitas Lampung, Bandar Lampung, 35145, Lampung, Indonesia

${ }^{4}$ Fakultas Hukum, Universitas Lampung, Bandar Lampung, 35145, Lampung, Indonesia
} \\ 2 Teknik Informatika, Universitas Lampung, Bandar Lampung, 35145, Lampung, Indonesia
}

\begin{abstract}
.
Perkembangan teknologi dapat menimbulkan kejahatan yang mana keberadaan internet tersebutlah yang kemudian memudahkan adanya kejahatan menggunakan teknologi informasi atau biasa kita sebut dengan cybercrime (kejahatan dunia maya) seperti tindak pidana body shaming dan cyber bullying. Terdapat masyarakat Indonesia saat ini banyak yang dalam melakukan tindakan body Shaming dan cyber bulying di media sosial dengan menghina bentuk tubuh, warna kulit, agama, hingga suku dan ras. Perlu adanya kesadaran masyarakat terkait bahayanya tindak pidana body shaming dan cyber bullying, undang undang yang mengatur, sanksi hukum, dan bagaimana mengetahui dan mengantisipasi body shaming dan cyber bullying
\end{abstract}

Keywords.

body shaming, cyber bullying, cyber crime

\section{PENDAHULUAN}

Setiap manusia memiliki Hak Asasi Manusia sejak lahir dan tidak dapat diganggu gugat. Hak Asasi Manusia tersebut dijamin negara yaitu setiap orang berhak atas kelangsungan hidup, bermasyarakat serta berhak atas perlindungan dari kekerasan dan diskriminasi termuat dalam Undang-Undang Dasar 1945 Pasal 28D ayat 1. Hak untuk berinteraksi dan memiliki status sosial juga dalam pemenuhan kebutuhan informasi dan sarana komunikasi manusia sebagai mahluk sosial. Seiring dengan perkembangan di bidang komunikasi dan informasi masa kini telah bertransformasi mengalami kemajuan yang sangat pesat, salah satu contoh kecanggihan yang di hadirkan sarana internet. Internet adalah jaringan komunikasi yang menggunakan media elektronik, yang saling terhubung dengan sistem global transmission control protocollinternet protocol suite (TCP/IPS) sebagai protokol

\section{* Corresponding author: deni.achmad1981@gmail.com}

Received 10 October 2021; Received in revised form 20 October 2021; Accepted 21 October 2021 
pertukaran paket (packet switching communication protocol) untuk dapat mengakses berbagai media komunikasi melalu dunia maya.

Kemudahan mengakses internet juga mendukung berbagai aspek, mulai dari pertukaran informasi hingga berkomunikasi dan bersosialisasi di dalam dunia maya melalui berbagai jenis media dan aplikasi yang ada. Perkembangan ini kemudian memudahkan dalam memenuhi kebutuhan informsi yang semakin cepat dan luas, dampaknya teknologi informasi dan komunikasi telah menyebabkan dunia menjadi tanpa batas (borderless), sehingga semua orang dapat dengan mudah mengakses apapun dan dimanapun melalui jejaring sosial seperti instagram, whatsapp, facebook, dan lainnya. Menurut Saxena situs jejaring sosial adalah media sosial yang paling popular, Media sosial tersebut memungkinkan anggota untuk berinteraksi satu sama lain. Interaksi terjadi tidak hanya pada pesan teks, tetapi juga termasuk foto dan video yang mungkin menarik perhatian pengguna lain. Semua posting (publikasi) merupakan real time, memungkinkan anggota untuk berbagi informasi seperti apa yang sedang terjadi [1].

Perkembangan teknologi informasi saat ini membawa pengaruh terhadap kehidupan sosial budaya manusia dan dapat di lihat dari perkembangan masyarakat. Saat ini, teknologi telah menjadi sebuah kekuatan yang dapat membelenggu perilaku dan gaya hidup manusia [2]. Melalui kekuatan jaringan sosial memudahkan manusia untuk mengekspresikan perilakunya. Teknologi informasi saat ini selain memberikan kontribusi bagi peningkatan kesejahteraan, kemajuan dan peradaban manusia. Kemajuan ini tidak hanya berdampak positif bagi kehidupan manusia namun sekaligus menjadi arena efektif bagi seseorang melakukan perbuatan melawan hukum [3]. Perkembangan teknologi dan informasi yang semakin pesat juga memunculkan kejahatan baru, kejahatan yang dilakukan dalam dunia cyber dan dapat dilakukan/diakses siapa saja baik anak-anak, remaja hingga orang dewasa.

Perkembangan teknologi tersebutlah yang kemudian menimbulkan kejahatan yang mana keberadaan internet tersebutlah yang kemudian memudahkan adanya kejahatan menggunakan teknologi informasi atau biasa kita sebut dengan cybercrime (kejahatan dunia maya) seperti tindak pidana body shaming, cyberbullying, pencemaran nama baik, pornografi, pembobolan rekening, dan lain-lain. Menurut Andi Hamzah kejahatan dunia maya adalah segala aktivitas tidak sah yang memanfaatkan jaringan komputer untuk tindak pidana, sekecil apapun dampak atau akibat yang timbul dari penggunaan komputer secara legal maupun ilegal merupakan suatu kejahatan [4]. Kejahatan yang marak terjadi dalam dunia maya adalah penghinaan citra tubuh (body shaming) dan cyberbullying, sehingga bukan tidak mungkin dengan semakin berkembangnya zaman dengan teknologi informasi dan berbagai macam jejaring sosialnya akan mengakibatkan perbuatan-perbuatan tersebut ini semakin meluas dan dapat berdampak buruk bagi keberlangsungan hidup manusia banyak termasuk dalam dunia maya.

Kejahatan body shaming adalah istilah yang merujuk kepada kegiatan mengkritik dan mengomentari secara negatif terhadap fisik atau tubuh orang lain atau tindakan mengejek/menghina dengan mengomentari fisik (bentuk tubuh maupun ukuran tubuh) dan penampilan seseorang [5]. Tetapi secara tidak langsung seseorang dapat melakukan body shaming dengan mengomentari bentuk tubuh seseorang dengan kata- kata yang menurut sebagian orang dianggap biasa saja, tetapi ada sebagian orang yang mempunyai kecenderungan bahwa semua omongan dari seseorang akan langsung dimasukkan ke dalam hati mereka dan itu sangat berdampak kepada psikis seseorang tersebut. Seseorang mengomentari tentang bentuk tubuh seseorang lainnya dengan dilakukan secara langsung tanpa melalui media sosial juga bisa. 
Body shaming dapat dimasukkan dalam dua kategori pelecehan non-verbal dan pelecehan verbal. Yang dikatakan pelecehan verbal ialah hal yang tidak semua orang tau tetapi dapat terkena sanksi pidana, seperti bersiul pada perempuan, bersiul tentu suatu hal sepele yang banyak orang sering melakukannya tetapi dapat dipidana karena pelecehan verbal jika digunakan untuk menggoda wanita. pelaku dapat dijerat kedalam Pasal 289 sampai Pasal 296 KUHP Karena dianggap melanggar rasa kesusilaan. Dalam hukum pidana tidak dikenal istilah pelecehan, akan tetapi termasuk dalam perbuatan cabul. Body shaming bisa menyerang siapa saja, anak-anak, tua, muda, perempuan bahkan laki-laki. Melakukan body shaming bisa juga di awali dengan dari diri kita sendiri yang kurang percaya diri dengan bentuk tubuh diri sendiri dan biasanya di ucapkan di media sosial maupun kepada teman-teman terdekat, sehingga lingkungan sekitar juga bisa mengomentari bentuk tubuh karena memang diawali dari diri sendiri yang kurang memiliki percaya diri.

Awalnya, body shaming hanya menjadi tren untuk bahan candaan saja, namun lama kelamaan menjadi serius hingga menjatuhkan atau menjelek-jelekkan orang lain yang mengakibatkan ketidaknyamanan dari orang yang menjadi objek body shaming tersebut. Ditambah lagi pada era digital seperti saat ini penggunaan kata-kata kerap sekali tidak terkontrol ketika menggunakan media sosial tidak secara bijak. Bila body shaming ini masih tetap berlanjut dalam jangka waktu yang lama maka akan mempengaruhi harga diri atau self-esteem seseorang, meningkatkan isolasi menarik diri, menjadikan seseorang rentan terhadap stress dan depresi serta rasa tidak percaya diri. Segala macam bentuk penghinaan yang dilakukan di media sosial / secara face to face ternyata termasuk tindak pidana. Jika sudah mengarah pada gambaran tertentu, yang kemudian membuat semua orang yang sebenarnya jika di ejek/di bercandai itu akan marah, baru itu memenuhi unsur pidana. Baik secara lisan maupun tulisan itu masuk kedalam tindak pidana. Itu sebenarnya adalah persoalan privat bahkan itu ada syaratnya. Jika mencemarkan itu minimal ada tiga orang yang mengetahui, maka itu sudah dianggap publish. Itu menjadi delik aduan, delik aduan adalah delik yang hanya dapat diproses apabila diadukan oleh orang yang merasa dirugikan atau telah menjadi korban. Maka dari itu, polisi tidak dapat berinisiatif untuk menindaklanjuti suatu kasus seperti dalam delik biasa, dan dalam delik aduan korban dapat mencabut laporannya jika permasalahan berhasil diselesaikan tanpa menempuh jalur hukum. Fakta yang terjadi di masyarakat sekarang ini banyak dari mereka yang suka melakukan body shaming di media sosial dengan menghina bentuk tubuh, warna kulit, agama, hingga suku dan ras.

Pada tahun 2018 Polisi telah menangani 966 pengaduan tentang Body shaming di seluruh Indonesia. Sebanyak 347 kasus di antaranya selesai, baik melalui penegakan hukum maupun pendekatan mediasi antara korban dan pelaku [6]. Menurut hasil survey yang dilakukan Twitter dan brand kosmetik Dove tahun 2014 lalu, wanita paling banyak jadi korban body shaming di internet. BBC memuat hasil jajak pendapat, dengan hasil lebih dari 5 juta cuitan Twitter memuat komentar negatif tentang kecantikan dan bentuk tubuh ideal. Ironisnya, 4 dari 5 post itu juga diunggah sesama wanita [7]. Survei menyebutkan bahwa sebanyak 93 persen wanita dan 83 persen pria mengungkapkan rasa tidak percaya dirinya akibat body shaming yang dilontarkan orang-orang di sekitarnya. Perut dan kaki menjadi bagian tubuh yang sering membuat mereka malu, tapi banyak juga yang menjadi sasaran body shaming pada wajah mereka [8]. Kejahatan yang marak terjadi pula dalam dunia digitalisasi adalah kejahatan cyberbullying atau perundungan di dunia maya. Menurut The National Crime Prevention Council, sebuah lembaga non-profit di Amerika Serikat yang bergerak dibidang mitigasi kejahatan mendefinisikan cyberbullying adalah sebuah kondisi ketika di internet, handphone, dan perangkat lain digunakan untuk mengirim sebuah pesan atau gambar yang ditujukan untuk melukai atau membuat rasa malu orang lain. 
Sementara pengertian lain mengenai cyberbullying meurut Hinduja dan Justin W. Patchin adalah sebah tindakan merugikan dan menggangu, berisi nada ancaman atau penghinaan, yang dilakukan oleh anak-anak atau remaja secara disengaja dan berulangulang melalui komputer, handphone, dan barang elektronik lainnya. Badan perlindungan anak internasional, UNICEF, mendefinisikan ini sebagai perundungan dengan menggunakan teknologi digital, yang bisa terjadi di media sosial, platform chatting, bermain game serta ponsel. Survei UNICEF tahun 2019 menyebut, 1 dari 3 remaja di 30 negara mengaku pernah jadi korban cyberbullying. Sementara 1 dari 5 remaja pernah bolos sekolah karena cyberbullying dan kekerasan. Peraturan perundang-undangan yang mengatur tentang permasalahan penghinaan body shaming dan cyberbullying ini diharapkan dapat melindungi korbannya sehingga untuk kedepannya permasalahan body shaming dan cyberbullying ini dapat dikurangi, dan juga diharapkan dapat memberikan efek jera terhadap pelaku penghinaan body shaming sehingga orang-orang dapat lebih berhati-hati untuk berkomentar tentang seseorang Pengabdian ini akan diadakan di Universitas Muhammadiyah Metro, dengan objek para Mahasiswa, dimana diketahui masih dibutuhkannya wawasan lebih mendalam tentang kesadaran akan kejahatan body shaming dan cyberbullying, undang-undang yang mengatur, sanksi pidana, dan cara menanggulangi atau mengantisipasi peredaran kejahatan body shaming dan cyberbullying di Universitas Muhammadiyah Metro.

Kegiatan Pengabdian ini dilakukan karena dipandang sangat diperlukan, untuk menyikapi, mengantisipasi, dan memberikan pemahaman kepada objek terkait kesadaran masyarakat terhadap pemahaman kejahatan body shaming dan cyberbullying, dengan cara ceramah secara langsung dan memberikan buku panduan atau buku saku, agar dapat lebih dipahami, dan diaplikasikan untuk kemaslahatan bersama. Kegiatan ini bertujuan untuk mengedukasi dan memberikan pehamanan tentang hukum pidana dalam hal ini pentingnya peningkatan kesadaran masyarakat tentang bahayanya kejahatan body shaming dan cyberbullying, serta peningkatan pemahaman hukum terhadap masyarakat dalam memerangi dan menanggulangi kejahatan tersebut. Kegiatan ini diharapkan dapat bermanfaat bagi para Mahasiswa atau masyarakat pada umumnya, untuk memberikan pemahaman mengenai pengaturan kejahatan body shaming dan cyberbullying, memberikan pemahaman hukum pidana terhadap pelaku dan korban kejahatan maya dalam hal ini body shaming.

\section{BAHAN DAN METODE}

Penulis menggunakan sumber data dalam rangka penyelesaian pengabdian ini, yaitu data sekunder. Data sekunder adalah data yang diperoleh dari studi kepustakaan. Data sekunder diperoleh dengan cara membaca, mengutip, mencatat serta menelaah bahan hukum primer, bahan hukum sekunder dan bahan hukum tersier.

\section{Bahan Hukum Primer}

Bahan hukum yang mempunyai kekuatan hukum yang mengikat, dalam hal ini yaitu Undang-Undang Nomor 11 Tahun 2008 tentang Informasi dan Transaksi Elektronik (UU ITE) pasal 27 ayat 3 jo.Pasal 45 ayat 3;

(1) Kitab Undang-undang Hukum Pidana (KUHP).

(2) UU Penghapusan Diskriminsi Ras Etnis. 


\section{Bahan Hukum Sekunder}

Bahan hukum sekunder yaitu bahan-bahan yang erat hubungannya dengan bahan hukum primer, seperti Peraturan Menteri Kominfo, dan sebagainya.

\section{Bahan Hukum Tersier}

Bahan hukum yang fungsinya melengkapi dari bahan hukum primer dan sekunder agar dapat menjadi lebih jelas, seperti kamus dan literatur-literatur yang menunjang dalam penulisan pengabdian ini.

Metode yang dipandang relevan untuk mencapai tujuan di atas ialah metode ceramah dan metode diskusi, dengan menyampaikan materi tentang bahaya dari cyberbullying dan body shaming, sesuai dengan Undang-Undang Nomor 19 Tahun 2016 atas perubahan Undang-Undang Nomor 11 Tahun 2008.

\section{HASIL DAN PEMBAHASAN}

Khalayak sasaran yang hadir sebagai peserta penyuluhan hukum berjumlah 20 orang Mahasiswa Universitas Muhammadiyah Metro. Dari hasil evaluasi awal, proses dan akhir terhadap khalayak sasaran peserta kegiatan dapat diketahui bahwa pelaksanaan kegiatan ini berjalan dengan baik hingga akhir kegiatan. Hasil kegiatan yang memuaskan ini ditandai dengan aktifnya peserta dalam penyampaian materi maupun dalam diskusi dan tanya jawab, pemahaman hukum serta adanya perubahan sikap peserta yang dapat dilihat dari hasil akhir kegiatan dengan membandingknnya sebelum dilakukan kegiatan penyuluhan. Pelaksanaan evaluasi dan hasilnya adalah sebagai berikut:

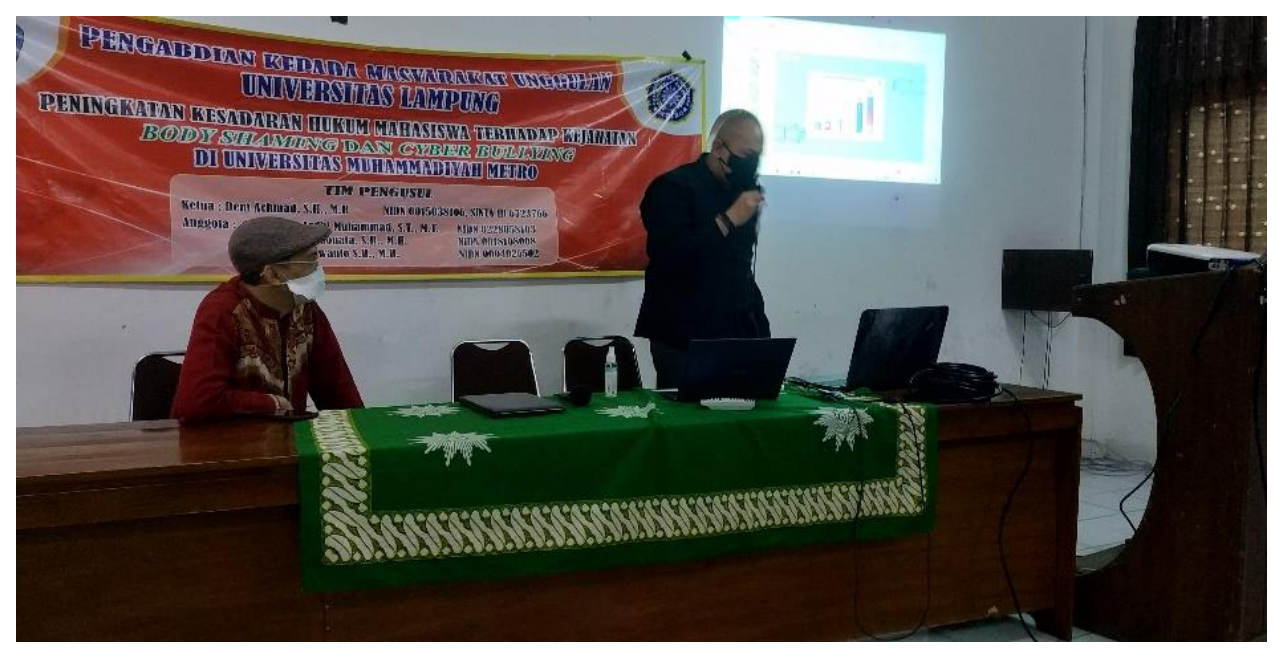

Gambar 1. Penyampaian Materi

Evaluasi awal dilaksanakan sebelum penyampaian materi dengan maksud mengetahui tingkat pengetahuan dan pemahaman hukum pidana khususnya tentang bahaya cyberbullying dan body shaming. Evaluasi ini dengan menggunakan daftar pertanyaan (pretest) yang berisikan 10 pertanyaan. Hasil evaluasi awal terhadap 20 orang Mahasiswa Universitas Muhammadiyah Metro menunjukkan bahwa kegiatan hanya memperoleh nilai rata-rata 50,00. Ini menunjukkan bahwa pemahaman Mahasiswa Universitas Muhammadiyah Metro masih rendah.

Penilaian partisipatif dilihat dari kuantitas pertanyaan yang diajukan oleh peserta penyuluhan berupa pertanyaan mengenai materi kegiatan penyuluhan. Pada saat berlangsung kegiatan pertanyaan-pertanyaan yang diajukan oleh peserta penyuluhan 
merupakan respon positif mengenai penyampaian materi untuk memahami materi yang disampaikan dan permasalahan-permasalahan hukum terkait materi yang disampaikan. Evaluasi proses dilaksanakan dengan melihat partisipasi aktif peserta selama kegiatan penyuluhan berlangsung.

Evaluasi akhir, dilaksanakan oleh tim dengan metode post-test pada akhir kegiatan. Evaluasi akhir ini dimaksudkan untuk mengetahui keberhasilan kegiatan penyuluhan dengan cara membandingkan pengetahuan dan pemahaman serta sikap sebelum dan sesudah kegiatan dilakukan. Perubahan yang dimaksud adalah perubahan pemahaman Mahasiswa/i sebagai peserta penyuluhan dari belum memahami menjadi paham serta, dari sikap tidak setuju menjadi setuju dengan materi yang disampaikan kepada peserta penyuluhan, maka penyuluhan hukum dikatakan cukup berhasil. Hasil evaluasi akhir setelah kegiatan menunjukkan telah terjadi peningkatan pengetahuan dan pemahaman hukum khususnya hukum pidana terkait dengan bahaya cyberbullying dan body shaming terkait materi yang disampaikan dalam penyuluhan hanya memperoleh rata-rata 50,00 , telah meningkat dengan evaluasi akhir dengan nilai rata-rata 90,00. Dilihat dari hasil akhir tersebut, kegiatan penyuluhan hukum ini cukup efektif dan berhasil dalam meningkatkan pengetahuan Mahasiswa Universitas Muhammadiyah Metro.

\section{KESIMPULAN}

Melalui kegiatan penyuluhan hukum di Universitas Muhammadiyah Metro sebagaimana diuraikan diatas:

1. Kegiatan penyuluhan hukum tentang bahaya cyberbullying dan body shaming telah memberikan pemahaman kepada Mahasiswa Universitas Muhammadiyah Metro yang ditandai dengan keaktifan peserta dalam kegiatan dalam hal saat pemateri menyampaikan materi dan dalam hal sesi tanya jawab, serta mengetahui bagaimana tindakan preventif dan represif apabila terjadi kasus cyberbullying dan body shaming.

2. Keberhasilan kegiatan penyuluhan hukum ini dikarenakan adanya keinginan dari masyarakat desa setempat untuk memahami hukum pidana tentang bahaya cyberbullying dan body shaming, serta mendapatkan dukungan penuh dari civitas academika Universitas Muhammadiyah Metro

\section{DAFTAR PUSTAKA}

[1] Nasrullah, R. (2015). Media sosial: Perspektif komunikasi, budaya, dan sosioteknologi. Bandung: Simbiosa Rekatama Media, 2016, 2017.

[2] Suhariyanto, B. (2012). Tindak Pidana Teknologi Informasi (Cybercrime): Urgensi Pengaturan dan Celah Hukumnya. Jakarta: PT RajaGrafindo Persada.

[3] Pomounda, I. (2015). Perlindungan Hukum Bagi Korban Penipuan Melalui Media Elektronik (Suatu Pendekatan Viktimologi. Jurnal Ilmu Hukum Legal Opinion Edisi 4, Volume 3.

[4] Makarim, E. (2003). Kompilasi Hukum Telematika. Cet 1. Jakarta: PT Raja Grafindo Persada.

[5] Chairani, L. (2018). Body Shame dan Gangguan Makan Kajian Meta-Analisis. Buletin Psikologi, 26(1), 12-27.

[6] Santoso, A. Polisi Tangani 966 Kasus Body Shaming Selama 2018. https://news.detik.com. Diakses tanggal 09 Februari 2021 Pukul 08.00 WIB.

[7] Anna, A. Dialami Dian Nitami, Survei Ungkap Body Shaming Dilakukan Oleh Sesama Perempuan. https://nakita.grid.id. diakses tanggal 09 Februari 2021 Pukul 10.30 WIB.

[8] Indonesia,C. Body Shaming,'Hantu' Yang Timbulkan Krisis Kepercayaan Diri. Diakses dari 
https://Www.Cnnindonesia.Com. Tanggal 10 Februari 2021 Pukul 11.30 Wib. 